This is an electronic reprint of the original article. This reprint may differ from the original in pagination and typographic detail.

Author(s): Ojala, Jari; Räihä, Antti

Title: Navigation Acts and the integration of North Baltic shipping in the early nineteenth century

Year: $\quad 2017$

Version:

Please cite the original version:

Ojala, J., \& Räihä, A. (2017). Navigation Acts and the integration of North Baltic shipping in the early nineteenth century. International Journal of Maritime History, 29(1), 26-43. https://doi.org/10.1177/0843871416678166

All material supplied via JYX is protected by copyright and other intellectual property rights, and duplication or sale of all or part of any of the repository collections is not permitted, except that material may be duplicated by you for your research use or educational purposes in electronic or print form. You must obtain permission for any other use. Electronic or print copies may not be offered, whether for sale or otherwise to anyone who is not an authorised user. 


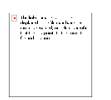

\section{Navigation Acts and the Integration of North Baltic Shipping in the Early Nineteenth Century}

\begin{tabular}{|r|l|}
\hline Journal: & International Journal of Maritime History \\
\hline Manuscript ID & Draft \\
\hline Manuscript Type: & Article \\
\hline Keywords: & Navigation Acts, Baltic, Early 19th Century, Shipping, Finland \\
\hline Abstract: & $\begin{array}{l}\text { This paper discusses how navigation acts affected shipping and commodity } \\
\text { trade from and to Northern Baltic during the early 19th century. We use } \\
\text { Finnish shipping and foreign trade as an example of trade integration at } \\
\text { the time. Finland can be used as a "laboratory case" to study the } \\
\text { importance of the Navigation Acts, as the eastern part of the area followed } \\
\text { the Russian legislation without the Navigation Act to restrict shipping to } \\
\text { domestic vessels, while the western part followed the Swedish legislation } \\
\text { with strict protection through the Swedish version of the Act } \\
\text { (Produktplakat). The paper argues that the role played by foreign vessels } \\
\text { in shipments of Finnish export goods was far more common during the } \\
\text { period than noted before, especially the British ships were used frequently } \\
\text { to carry Finnish export cargoes. }\end{array}$ \\
\hline
\end{tabular}


Navigation Acts and the Integration of North Baltic Shipping in the Early Nineteenth Century

\section{INTRODUCTION}

The British Navigation Acts of 1651 and 1660 were aimed to protect the country's foreign trade shipments aboard domestic vessels - especially at the cost of Dutch shipping. Indeed, this legislation was one reason for the growth of British shipping. ${ }^{1}$ The Navigation Acts have subsequently been criticised, however, by numerous authors - not to mention the vast literature discussing the pros and cons of (state) regulation in shipping and other activities ${ }^{2}$. Critics include Adam Smith, who saw this legislation as detrimental to British trade and diminishing British trade with Europe at the costs of the colonies - though even he saw the Act as "perhaps, the wisest of all commercial regulations of England"3. German economist Friedrich List, in turn, saw the Navigation Act as a primary cause for expansion of English trade in the Baltic Sea area. ${ }^{4}$

A similar kind of legislation was passed in a number of countries, including Sweden in $1724^{5}$, when the so-called "Commodity Ordinance" (produktplakat), the Swedish Navigation Act, came into force. The aim of this Act was to secure import trade shipments for domestic vessels - especially in order to secure imports of salt. ${ }^{6}$ Namely, the Ordinance prohibited

\footnotetext{
${ }^{1}$ See e.g. John H. Clapham, 'The last years of the Navigation Acts', The English Historical Review, 25, No. 99 (1910), 480-501; Violet Barbour, 'Dutch and English merchant shipping in the seventeenth century', The Economic History Review, 2, No. 2 (1930), 261-290; Ralph Davis, The Rise of the English Shipping Industry. In the Seventeenth and Eighteenth Centuries (London 1962), 306-308; James E. Farnell, 'The Navigation Act of 1651, the First Dutch War, and the London Merchant Community', The Economic History Review, 16, No. 3 (1964), 439-454; Sarah Palmer, Politics, Shipping and the Repeal of the Navigation Laws (Manchester 1990), passim; Yrjö Kaukiainen, A History of Finnish Shipping (Abingdon 1993), 33; Sakari Heikkinen, Suomeen ja maailmalle -Tullilaitoksen historia (Helsinki 1994), 86, 88-89.

${ }^{2}$ On the regulation of shipping see for example Sarah Palmer, 'Government and the British Shipping Industry in the Later Twentieth Century', in Gelina Harlaftis, Stig Tenold and Jesús M. Valdaliso, eds., The World's Key Industry. History and Economics of International Shipping (Basingtoke 2012), 124 - 141.

"Classic" property right discussion, for example in Armen A. Alchian and Harold Demsetz, 'The property right paradigm', The Journal of Economic History, 33, No. 1 (1973), 16-27.

${ }^{3}$ Adam Smith, An Inquiry into the Nature and Causes of the Wealth of Nations, Volume I-II (Indianapolis 1776/1976) I, 463-465; II, 596-597.

${ }^{4}$ Oscar Albert Johnsen, 'The Navigation Act of 9 October, 1651', History, 34, No. 120-121 (1949), 89.

${ }^{5}$ Excluding areas annexed to Russia in the treaties of Nystad (Uusikaupunki) in 1721 and Åbo (Turku) in 1743. This latter territory became known as Old Finland

${ }^{6}$ On the Swedish mercantilist legislation on shipping and trade see especially Eli F. Heckscher, Sveriges ekonomiska historia från Gustav Vasa I:2 (Stockholm 1936), 675-676; Eli F. Heckscher, Sveriges ekonomiska historia från Gustav Vasa II:2 (Stockholm 1949), 669-678; Christian Ahlström, Spår av hav, yxa och penna, Historiska sjöolyckor i marinarkeologiskt källmaterial (Helsingfors 1995), 180-198; Stefan Carlén, Staten som marknadens salt, En studie i institutionsbildning, kollektivt handlande och tidig välfärdspolitik på en strategisk varumarknad i övergången mellan merkantilismen och liberalismen 1720-1862 (Stockholm 1997), 247-252.
} 
foreign merchants from transporting to Sweden goods that did not originate in their own countries. As sailing in ballast to Sweden and Finland to pick up export goods was unprofitable, this law in practice also protected export shipping for domestic vessels and motivated merchants to invest in shipping. The Swedish Navigation Act was justified by the fact that it would stimulate Sweden's own shipping industry - in practice at the cost of the Dutch and British ships - and also strengthen Swedish naval power as it would lead to an increase in capable seamen who could be hired from the merchant fleet in time of war. ${ }^{7}$ Moreover, according to the early eighteenth century Swedish legislation, imports and exports on board foreign ships were subject to 50 per cent higher customs fees than were domestic vessels. By the end of the eighteenth century these customs fees for foreign ships carrying Swedish (and Finnish) timber cargoes rose up to 280 per cent higher than the customs for domestic ships. ${ }^{8}$ Thus foreign trade shipments were mainly carried by domestic vessels.

Contemporaries already perceived the problems of the Swedish Navigation Act - as did Smith in Britain. A Finnish representative at the Swedish 1765 Diet, Anders Chydenius, argued that the Swedish Navigation Act was only beneficial to large merchant houses as it protected their business, but harmful to the state and most of the citizens. According to him, the Act not only restricted foreign trade and increased the prices of (imported) commodities, but also demand for Swedish export items would diminish as the prices would be higher due to the more expensive freight costs. Chydenius stated clearly in his published pamphlet that it would be more beneficial to use cheap foreign ships in foreign trade shipments. ${ }^{9}$ Many authors after him have criticized the Swedish Navigation Act as mercantilist and protectionist, and thus harmful. These critics include Eli Heckscher, who called the Commodity Ordinance the "fundamental law" of the old Swedish mercantile shipping

\footnotetext{
${ }^{7}$ Lars Magnusson, 'Comment on The Source of Our Country's Weakness', in Maren Jonasson and Pertti Hyttinen eds., Anticipating The Wealth of Nations. The Selected works of Anders Chydenius (1729-1803) (Abingdon 2012), 139-141.

${ }^{8}$ Staffan Högberg, Utrikes handel och sjöfart på 1700-talet. Stapelvaror i svensk export och import 1738-1808 (Lund 1969), 28; Sven-Erik Åström, From Tar to Timber. Studies in Northeast European Forest Exploitation and Foreign Trade 1660-1860 (Helsinki 1988), 41.

9 Anders Chydenius, 'The Source of Our Country's Weakness (original: Källa Til Rikets Wan-Magt 1765)' in Maren Jonasson and Pertti Hyttinen eds., Anticipating The Wealth of Nations. The Selected works of Anders Chydenius (1729-1803) (Abigdon 176/2012), 124 - 131 - See also Magnusson, 'Comment on The Source', 139141; Jouko Nurmiainen, 'Kommentar till texterna 13 - 14', in Maren Jonasson and Pertti Hyttinen eds., Anders Chydeniys samlade skrifter. Band 1. 1751 - 1765, (Helsinki and Stockholm 2012), 321 -325; Pentti Virrankoski, Anders Chydenius. Demokraattinen poliitikka valistuksen vuosisadalta (Helsinki 1986), 136-144.
} 
${ }^{10}$ Eli F Heckscher, Produktplakatet. Den gamla Svenska sjöfartspolitikens grundlag, in Eli F. Heckscher (ed.), Ekonomi och historia (Stockholm 1922), 164. See also Ian G. Layton, The Evolution Upper Norrland's Ports and Loading Places 1750-1976 (Umeå 1981), 72 - 73.

${ }^{11}$ Leo Harmaja, Suomen tullipolitiikka Venäjän vallan aikana 1, vuoteen 1859 (Porvoo 1920), 6, 856-859; Åström, From Tar to Timber, 13, 41. - See also Jari Ojala, 'Från svenskt till ryskt system. Det finska näringslivets samarbete med konsuler I utlandet på 1800-talet', in Aryo Makko and Leos Müller, eds., I främmande hamn. Den Svenska och svensk-norksa konsultjänsten 1700-1985 (Lund 2015), 212-223.

${ }^{12}$ Magnusson, 'Comment on The Source', 140; Layton, The Evolution, 72-73. 
nationality of ships, and moreover, as Vyborg was again lost to the Soviet Union after the Second World War, researchers have also had difficulties in accessing local archival sources. Therefore this paper will collate information from the Danish Sound Toll Accounts Online database $^{13}$ and the archival material from Vyborg and another important town in the area, Fredrikshamn (in Finnish Hamina) - especially the Archives of Old Finland's Unification Committee from the early $19^{\text {th }}$ century. The recently published Danish Sound Toll registers online database enable us to analyse more precisely the period of growth in shipping between the Baltic and the North Sea over a very long period of time, and especially from the early to mid-nineteenth century - as earlier source publications based on the Danish Sound Toll registers enable us to study shipping and trade patterns only up to the $1790 \mathrm{~s}^{14}$ This dataset enables us also to identify the nationality ${ }^{15}$ of the ships that carried export cargoes from Finnish seaports.

The Baltic and North Sea connections during the early $19^{\text {th }}$ century can be used also to study more general patterns of trade and shipping. Namely, the decline in the cost of international transport and growth of world trade, together with emerging industrialization were the primary causes for the so-called first era of globalization from the turn of the eighteenth and nineteenth centuries. ${ }^{16}$ The growth of trade and shipping can be also witnessed in the "mother of all trades", in shipping between the Baltic and the North Sea. ${ }^{17}$ Globalization in liberal terms also refers to the abolition of mercantilist protectionism. However, one can hardly argue that early nineteenth century Europe was "liberal" in more modern terms as all kinds of protective legislation still

\footnotetext{
${ }^{13}$ On the STRO project see especially Erik Gøbel, 'The Sound Toll Registers Online Project, 1497-1857' International Journal of Maritime History, 22, No. 2 (2010), 305-324; Werner Scheltjens and Jan Willem Veluwenkamp, 'Sound Toll Registers Online: Introduction and First Research Examples', International Journal of Maritime History, 24, No. 1 (2012), 301; The data is available at: www.soundtoll.nl

${ }^{14}$ Nina Ellinger Bang and Knud Korst, Tabeller over Skibsfart og Varetransport gennem Øresund 1661-1783 og gennem Storebelt 1701-1748: 1. Tabeller over Skibsfarten (København 1930); Nina Ellinger Bang and Knud Korst, Tabeller over Skibsfart og Varetransport gennem Øresund 1661-1783 og gennem Storebelt 1701-1748: 2. Tabeller over Varetransporten: 2, 1721-1760 (København 1945); Hans Chr. Johansen, Shipping and trade between the Baltic area and western Europe 1784-95 (Odense 1983).

${ }^{15}$ Source critical analysis of Sound Toll Account books especially in Sven-Erik Åström, From Cloth to Iron. The Anglo-Baltic Trade in the late Seventeenth Century. Part II. The Custom Accounts as Sources for the Study of the Trade (Helsinki 1965), passim; Kalevi Ahonen, From Sugar Triangle to Cotton Triangle (Jyväskylä 2005), 23-28.

${ }^{16}$ Jeffrey G. Williamson, 'Globalization, Convergence, and History', The Journal of Economic History, 56, No. 2 (1996), 277-306; Jeffrey G. Williamson and Kevin O’Rourke, Globalization and History. The Evolution of a Nineteenth Century Atlantic Economy (Cambridge 1999), passim.

${ }^{17}$ Overviews on Baltic trade and shipping especially in: Michael North, Geschichte der Ostsee: Handel und Kulturen (Munich 2011), Ahonen, From Sugar Triangle; Knoppers, Jake V. Th, Dutch trade with Russia from the time of Peter I to Alexander I: A quantitative study in eighteenth century shipping (1 - 3) (Montréal 1976); Milja van Tielhof, The 'Mother of All Trades': The Baltic Grain Trade in Amsterdam from the Late Sixteenth to the Early Nineteenth Century (Leiden 2002).
} 
existed, especially in foreign trade and shipping - also after the repeal of the abovementioned Navigation Acts. ${ }^{18}$

Based on the new evidence from the Sound Toll Registers Online, this paper argues that the role played by the foreign ships was already important in carrying Finnish export trades during the 1820 s and 1830s. We will show that the cargoes from Vyborg and Fredrikshamn were mainly carried by foreign vessels (notably British) as the local merchants invested to increase sawmill capacity. On the western coast of Finland, business remained the same as during the period of Swedish domination period: the entrepreneurs invested in shipbuilding and exported large quantities of tar to international markets. This period also witnessed a growth in export trade from Finland beyond the Baltic Sea and consequently, a growth in shipping. It was also a period of structural change when timber overtook tar as the most important Finnish export item, and the focal area in the Finnish economy moved from the North-West to the South-East. Thus the paper argues that the rise in timber exports and the large share of foreign ships in carrying on these trades witnessed the integration of the Finnish economy into the rest of Europe at the time. The earlier (Finnish) research literature has argued that most of the exports were carried by Finnish ships from Vyborg area as well. Sven Erik Åström, for example, suggests that only from the 1840s were additional customs and shipping dues abolished from British and other ships carrying Finnish timber exports. ${ }^{19}$

This paper will first introduce the general patterns of growth and structural change in Finnish shipping and trade, followed by an analysis of the nationality of this shipping and present some brief conclusions.

\section{GROWTH AND STRUCTURAL CHANGE IN FINNISH EXPORTS AND SHIPPING}

During the period 1815 - 1870 the volume of Finnish exports grew tenfold. ${ }^{20}$ Finnish shipping by sail also at first faced a period of growth (ca. 1760s to 1870s), and then stagnation (ca. 1880s onwards). (Figure 1) By the early 1870s Finnish shipping tonnage per capita was the fifth largest

\footnotetext{
${ }^{18}$ See especially Eli F. Heckscher. Merkantilismen, I-II (Stockholm 1953); Lars Magnusson, Mercantilism: the shaping of an economic language (Abingdon 2002).

19 Åström, From Tar to Timber, 41.

${ }^{20}$ Riitta Hjerppe, The Finnish Economyc 1860 - 1985. Growth and Structural Change (Helsinki 1989), passim.
} 
in the world. ${ }^{21}$ The Finnish merchant fleet was more frequently used not only for carrying domestic export and import cargoes, but also in international freight cargo trades. ${ }^{22}$

Figure 1. Number of ships passing the Danish Sound to or from Finland (left axis1815 -1853) and tonnage (in lasts) of Ships in Finnish Towns (right axis, 1815 - 1887)

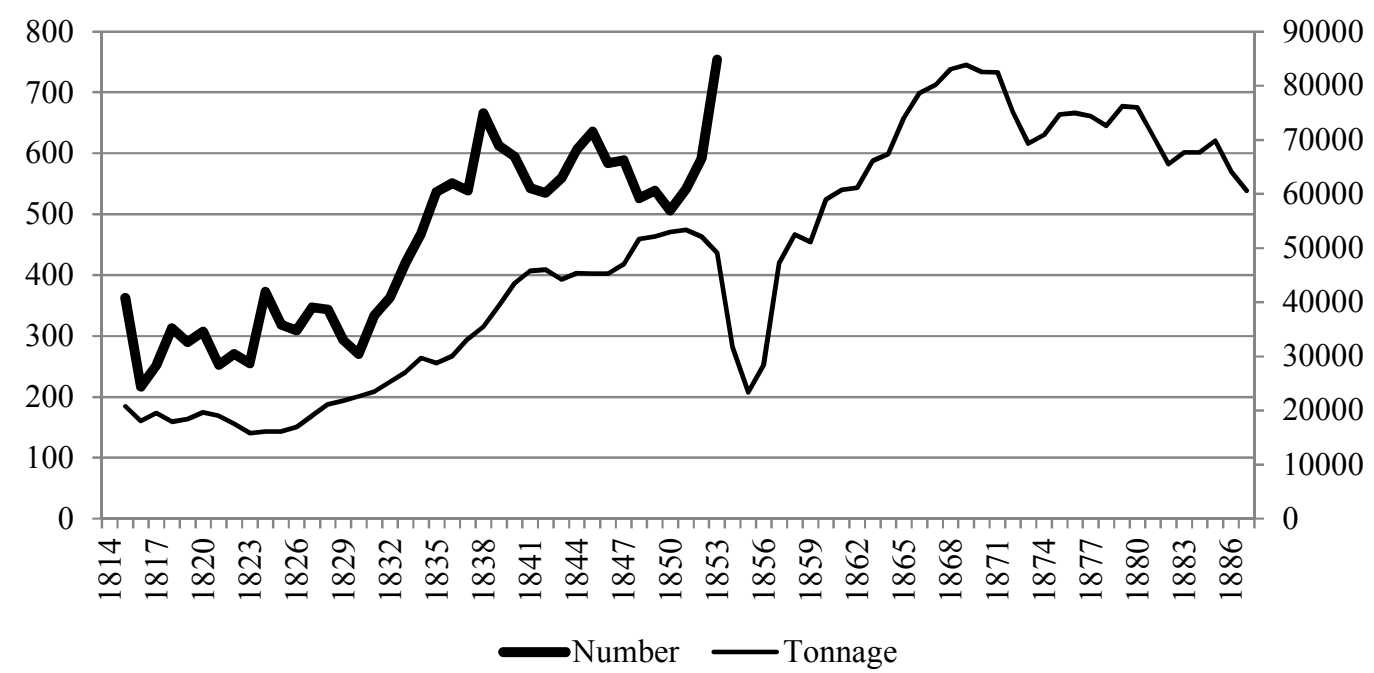

Sources: Jari Ojala, Tehokasta liiketoimintaa Pohjanmaan pikkukaupungeissa. Purjemerenkulun kannattavuus ja tuottavuus 1700-1800-luvulla (Helsinki 1999) and Sound Toll Registers Online (STRO).

The growth of Finnish exports and shipping accelerated during the first part of the nineteenth century as a consequence of international economic growth and the liberalisation of international shipping that led to the repeal of the British Navigation Acts in 1849 and to the closing of the Danish Sound Toll in $1857 .{ }^{23}$ Figure 1 shows, however, that the number of ships passing through the Danish Sound either from or to Finland increased more rapidly than the Finnish shipping tonnage, especially during the 1830s. This may be due to the fact that either more ships from other countries carried the Finnish cargoes or/and the Finnish ships were more frequently used for carrying freight outside the Baltic area, or that Finnish vessels were used inside the Baltic and thus did not pass the Sound Toll.

\footnotetext{
${ }^{21}$ Kaukiainen, A History of Finnish Shipping.

${ }^{22}$ See especially Kustaa Hautala, 'From Black Sea to the Atlantic. Finnish Merchant Shipping in the late Nineteenth Century', Scandinavian Economic History Review, 19, No. 1 (1971), 12-22; Yrjö Kaukiainen, 'International Freight Markets in the 1830s and 1840s: The Experience of a Major Finnish Shipowner', Research in Maritime History, 14, No. 1 (1998), 1 - 27; Jari Ojala, 'Approaching Europe: The merchant networks between Finland and Europe during the eighteenth and nineteenth centuries', European Review of Economic History, 1, No. 3 (1997), 323-352.

${ }^{23}$ Ahonen, From Sugar Triangle; Palmer, Politics, passim.
} 
Until recently, the big picture of this trade - especially as regards the carrying of cargoes - has been rather difficult to decipher due to shortcomings in the domestic sources. Namely, Finland was part of the Swedish kingdom until 1809 and during that period the shipping and trade were carefully documented in statistics compiled by the Swedish Board of Trade. ${ }^{24}$ During the period of Russian rule, from 1809 onwards, similar information was still compiled by the authorities for the Finnish Senate, but summaries based on this data were not drawn until the mid-nineteenth century, when the ongoing series of trade and shipping statistics emerged.

Thus, we have a period of around 50 years of Finnish history where we know less about the shipping and trade patterns in general, although this was specifically a period of growth and structural change in foreign trade and shipping. Due to the sources available the focus in the Finnish literature has previously been on either the late eighteenth-century development ${ }^{25}$, or on the period of decline during the late nineteenth century ${ }^{26}$. The developments during the "take off" period of Finnish shipping and export trade during the early nineteenth century have attracted less attention in Finnish historiography. ${ }^{27}$

Figure 2. Ships passing the Danish Sound (left axis) and share of Finnish ships (\%, right axis), 1503 - 1850 (every five years)

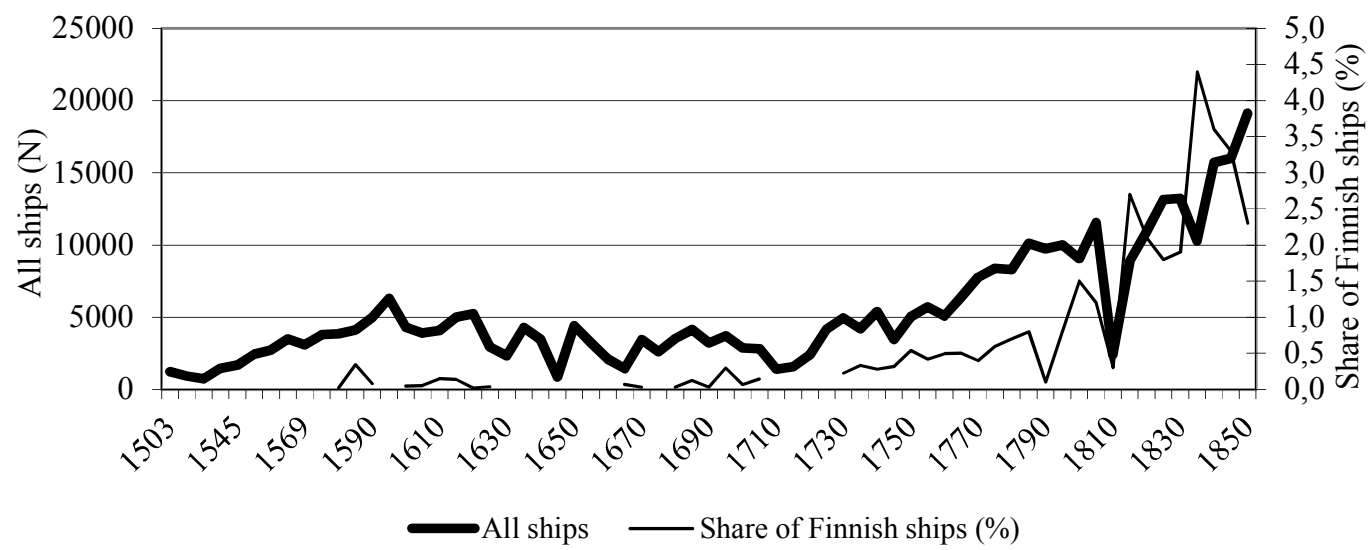

Sources: Rigsarkivet, Copenhagen, Øresunds toldkammarets arkiv, Øresunds skiblistebøger 1800-1850 and Bang \& Korst, 1930; Johansen, 1983

${ }^{24}$ Historisk statistik för Sverige. Utrikeshandel 1732-1970. (Vol. 3) (Stockholm 1972); Högberg, Utrikeshandel; Rolf Vallerö, Svensk handels- och sjöfartsstatistik 1637 - 1813. (Stockholm 1969).

${ }^{25}$ Aulis J. Alanen, Der Aussenhandel und die Schiffahrt Finnlands im 18. Jahrhundert (Helsinki 1957), passim; Jan-Erik Börman, Genom Öresund: Öresundstullen - skeppsfarten på Finland 1500-1800 (Helsingfors 1981); Elmo E. Kaila, Pohjanmaa ja meri 1600-ja 1700-luvuilla (Helsinki 1931).

${ }^{26}$ Hautala, From Black Sea; Yrjö Kaukiainen, Sailing into Twilight. Finnish Shipping in an Age of Transport Revolution, 1860-1914 (Helsinki 1991).

${ }^{27}$ See however e.g. Kauko E. Joustela, Suomen Venäjän kauppa autonomian ajan alkupuoliskolla vv 1809 - 65 (Helsinki 1963); Lauri I. Kaukamaa, Porin puutavarakaupasta ja metsänkäytöstä kaupungin kauppapiirissä "suuren laivanvarustustoimen" aikana 1809 - 56 (Helsinki 1941); Oscar Nikula, Malmska handelshuset $i$ Jacobstad (Helsingfors 1948); Ojala, Tehokasta; Åström, From Tar to Timber. 
The number of ships cleared in the Danish Sound tripled from the mid-eighteenth century until the mid-nineteenth century, and doubled in the period from 1820 to 1850.(Figure 2) Freight rates in international trade declined especially after the Napoleonic Wars which, in turn, accelerated the growth of trade and, thus, increased the need for shipping capacity. ${ }^{28}$ In general, the tonnage growth of Finnish shipping and the increase in clearance of ships in the Danish Sound witnesses the ongoing first era of globalization in international trade. ${ }^{29}$ As these figures are only calculated from the number of ships, the total volume of shipping is underestimated, as the average size of ships increased during the period. Unfortunately, the Sound Toll Data does not reveal the tonnage of ships passing through the Sound - or rather the tonnage figures should be calculated from different cargo loads which makes it difficult, though not impossible.

Figure 3. Number of ships carrying tar or timber as their main cargo from Finland through the Danish Sound 1815 - 1853

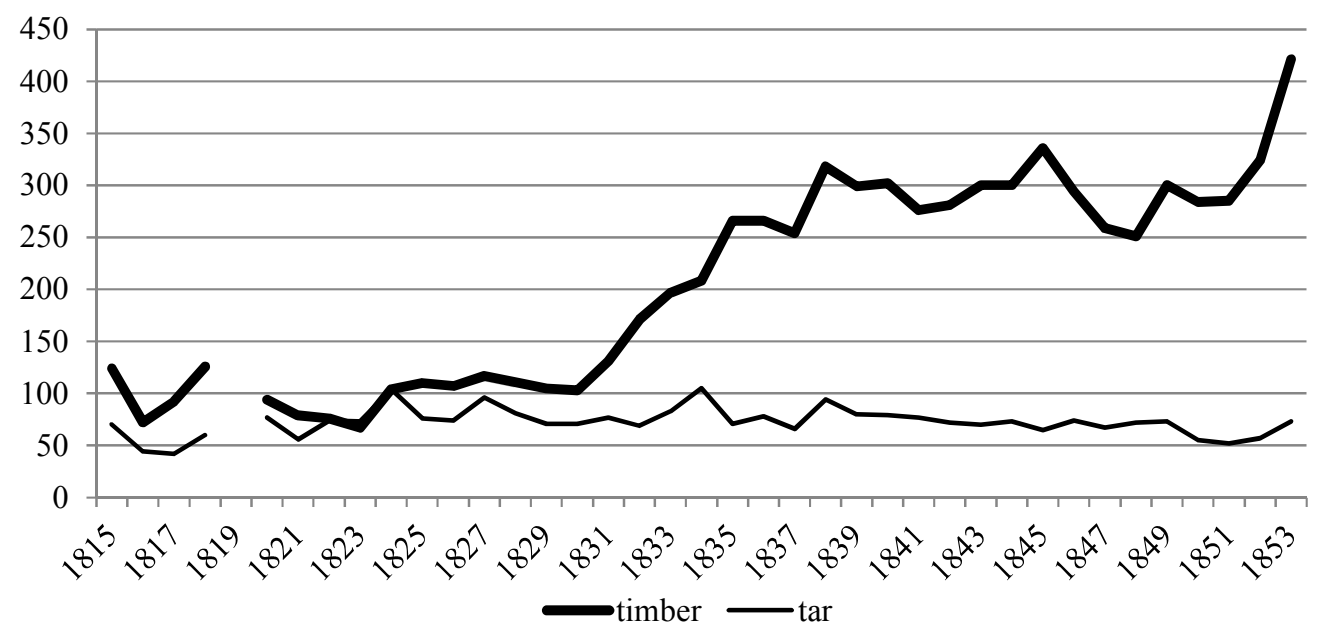

Source: STRO

The Sound Toll Data suggests, thus, that not only did the absolute volume of Finnish shipping rise during the early nineteenth century, but also its share of total shipments from and to the Baltic Sea. (Figure 2) This share was, however, rather modest; in 1800 the share of

\footnotetext{
${ }^{28}$ C. Knick Harley, 'Ocean Freight Rates and Productivity, 1740-1913: The Primacy of Mechanical Invention Reaffirmed' Journal of Economic History, 48, No. 4 (1988), 851-876; Douglass C. North, 'Ocean Freight Rates and Economic Development 1750-1913' Journal of Economic History, 18, No. 4 (1958), 537-555.

${ }^{29}$ Williamson and O’Rourke, Globalization.
} 
Finnish ships in the Danish Sound was 1.5 and in 1835 4.4. per cent respectively. As Finnish ships carrying tar and timber were typically rather large when compared, for example, to Swedish vessels that were built to carry heavy cargoes of iron, the tonnage of Finnish shipping was most probably higher than Figure 2 shows. ${ }^{30}$

The early nineteenth century also witnessed also a rather significant structural change in Finnish export trade as timber overtook tar as the most important Finnish export item. ${ }^{31}$ As tar had dominated the export trade for two centuries, timber was now established as the main export item and it remained in this position until the 1950s. This change can also be witnessed in the Sound Toll accounts. (Figure 3)

There are both endogenous and exogenous reasons for this change in exports - both, however, interlinked with each other. The endogenous factors include the growth in number of sawmills in Finland from the eighteenth century after the introduction of Dutch fine-blade sawmill technology. ${ }^{32}$ This increase, however, was more pronounced in south-eastern part of Finland, namely, in the Vyborg area that was already annexed to Russia after the Great Northern War of 1721. Thus, the exports of the Vyborg area were not included in the Swedish(-Finnish) statistics for the eighteenth century. During the eighteenth century Vyborg emerged as one of the largest timber exporting areas in northern Europe. Timber export shipments in this area, however, were mainly in the hands of foreigners - first the Dutch, thereafter the British - as Russia did not have a Navigation Act or other protective measures similar to those of Sweden to prevent this kind of activity. Therefore the local Vyborg merchants were more interested in establishing new sawmills in the countryside than in building ships; thus the fleet of the town was rather modest. ${ }^{33}$ Moreover, the other town in the area, Fredrikshamn (in Finnish Hamina), also had a modest fleet during the 18th century which, however had almost disappeared by the turn of the

\footnotetext{
${ }^{30}$ Jari Ojala, 'Productivity and Technological Change in Eighteenth- and Nineteenth-Century Sea Transport: A Case Study of Ship Efficiency in Kokkola, Finland, 1721-1913' International Journal of Maritime History, 9, No. 1 (1997), 93-123.

${ }^{31}$ See especially Kustaa Hautala, Suomen tervakauppa 1856-1913. Sen viimeinen kukoistus ja häviö sekä niihin vaikuttaneet syyt (Helsinki 1956), passim; Kustaa Hautala, European and American Tar in the English Market During the Eighteenth and Early Nineteenth Centuries (Helsinki 1963); Yrjö Kaukiainen, 'Foreign Trade and Transport' in Jari Ojala, Jari Eloranta and Jukka Jalava, eds., The Road to Proseperity. An Economic History of Finland (Helsinki 2006), 132-134; Åström, From Tar to Timber, 60, 188 - 189.

32 Jorma Ahvenainen, Suomen sahateollisuuden historia (Porvoo 1984); Markku Kuisma, Kauppasahojen perustaminen Suomessa 1700-luvulla (1721-1772). Tutkimus päätöksentekoprosessista (Helsinki 1983); Markku Kuisma, Metsäteollisuuden maa. Suomi, metsät ja kansainvälinen järjestelmä 1620-1920 (Jyväskylä 1993). ${ }^{33}$ Ahvenainen, Suomen sahateollisuuden; Petri Karonen, 'Talouselämä 1780-luvun jälkipuoliskolta Vanhan Suomen ajan loppuun' in Yrjö Kaukiainen, Risto Marjomaa and Jouko Nurmiainen, eds., Viipurin Läänin historia IV: Vanhan Suomen aika (Keuruu 2013), 394-415.
} 
19th century. ${ }^{34}$ Nevertheless, Fredrikshamn was also a fairly significant port for timber exports, as can be seen in the Sound Toll.

Another institutional arrangement also affected the rise of the timber trade in South-East Finland; Russia, unlike Sweden, had no such restrictions on the use of forest resources - and the restrictions passed were not efficiently enforced, which made large-scale logging possible. ${ }^{35}$ Therefore merchants in the Vyborg and Fredrikshamn area were free to exploit the forest resources ${ }^{36}$, whereas in the "Swedish" part of Finland more value added was to be gained by producing tar, pitch and ships using similar wood as a raw material. On this "Russian" side of Finland there were no such a restrictions on using timber resources as was the case on the "Swedish" side - thus, for entrepreneurs it was profitable to establish as many sawmills as possible; especially as they did not (have to) invest in expensive ships as did the merchants in western Finland ${ }^{37}$ Furthermore, the Vyborg and Fredrikshamn exports were linked to hinterlands in eastern Finland with vast forest resources through inland water routes, up to towns of Joensuu, Varkaus, and Kuopio, alongside the Lake Saimaa waterway. Therefore, by the 1780s Vyborg and Fredrikshamn exported more sawn goods than the whole of the Swedish realm combined.

During the late $18^{\text {th }}$ century even in Russia more restrictive policies were implemented to protect the forests. The aim was to secure timber resources suitable for shipbuilding - the motive was not, however, to promote merchant shipping but rather to safeguard the interests of the navy. ${ }^{38}$ Yet these restrictions had only a modest effect and they were quite widely violated. ${ }^{39}$ Nevertheless, the total volume of timber exported from Vyborg diminished rapidly from the 1780 s total of 150,000 tolts to only 5,000 tolts in $1811 .^{40}$ This volume, however, soon regained the late $18^{\text {th }}$ century figures during the first decades of the $19^{\text {th }}$ century.

\footnotetext{
${ }^{34}$ Karl O. G. Hannikainen, Vanhan Suomen eli Viipurin läänin oloista 18:lla vuosisadalla (Tampere 1888); Sigurd Nordenstreng, Haminan kaupungin historia II osa (Hamina 1910).

35 e.g. Oskar A. Kallio, Viipuri läänin järjestämisestä muun Suomen yhteyteen (Helsinki 1901); Robert Lagus, 'Det Gamla Finlands rättsliga förhållanden vid reunionen 1811', Juridiskt Album, 1, No. 3 (1862).

${ }^{36}$ Kaukiainen, Foreign Trade, 133 - 138

${ }^{37}$ Ojala, Från svenskt, 216; Karonen, Talouselämä.

${ }^{38}$ Jyrki Paaskoski, Vanhan Suomen lahjoitusmaat (Helsinki 1997), 22- 223; Elias Orrman and Jyrki Paaskoski, Vanhan Suomen arkistot (Helsinki 2012), 139 - 141; Jyrki Paaskoski, 'Vanhan Suomen aikakausi. Karjala osana Venäjän keisarikuntaa 1710-1811' in Pekka Nevalainen and Hannes Sihvo, eds., Karjala. Historia, kansa, kulttuuri (Helsinki 1998), 92-124; Tapani Tasanen, Läksi puut ylenemähän. Metsien hoidon historia Suomessa keskiajalta metsäteollisuuden läpimurtoon 1870-luvulle (Helsinki 2004), 161-167.

${ }^{39}$ Kallio, Viipuri, 215-221; Lagus, 'Det Gamla', 166-167.

${ }^{40}$ Archives of Old Finland's Unification Committee, received documents (from Vyborg Town Council, 22.4.1812, 8.2.1813), National Archives of Finland, Helsinki; also see Archives of Old Finland's Unification
} 
Russia also established protective measures to control foreign trade and shipping during the $18^{\text {th }}$ century. For example, the merchants of Fredrikshamn (at the time a part of Russia) in 1744 applied for and were granted restrictions on their export trade and shipping which, in fact, was similar to the Swedish Navigation Act. Moreover, similar regulations followed in 1782 and 1800. With these regulations export customs were lowered if the cargoes were carried on board domestic vessels and/or using mainly Russian sailors as crew. There was, indeed, a short period of growth of locally owned vessels from the 1780s in Fredrikshamn (up to 12 ships). These attempts failed - at least in case of Fredrikshamn: the town had only one small vessel in 1804 1810 that was locally built, and even that was captured by the British in 1810 . Moreover, these locally owned ships were mainly used in coastal shipping, not to carry foreign trade shipments. ${ }^{41}$ Thus the majority of export shipments during the $18^{\text {th }}$ century were carried both from Vyborg and Fredrikshamn by foreign vessels and the volume and value of exports increased around the turn of the $19^{\text {th }}$ century ${ }^{42}$. In the case of Fredrikshamn, especially Danish ships were frequently used. $^{43}$

When rest of the Finland was annexed to Russia in 1809 as an autonomous grand duchy, Vyborg and other areas of so-called "Old Finland" were reunited with Finland in 1812. Only from here onwards were the Vyborg exports and shipping included in the Finnish statistics and the Finnish (Swedish) legislation was also introduced in the Vyborg area - at least to a certain extent. Nevertheless, the role played by foreigners in shipping did not diminish as can be seen later in this article - simply due to the fact that the volumes of timber Vyborg was exporting were far too large for the Finnish merchant fleet. Furthermore, the major aim of the Swedish Navigation Act was to prevent import, not export trade with foreign ships, though in practice it had also diminished the export shipments.

The South-West Finland timber shipments, obviously, provided cargo carrying opportunities for to the ship owners of western Finland - as did the whole Russian empire. Russia had no

Committee, Received documents (from Fredrikshamn Town Council, 18.4.1812), National Archives of Finland, Helsinki.

${ }^{41}$ Imperial Customs Tariff 1744 Archives of Old Finland's Unification Committee, received documents (from Fredrikshamn Town Council, 2.5.1812, 23.5.1812), National Archives of Finland, Helsinki.

${ }^{42}$ During the years $1782-1793$ altogether 24 ships docked to Fredrikshamn and in the years $1797-180611$ ships. As the ships were larger, the value of exports doubled. Many of these ships arrived in ballast as the value of imports did not increase. See Hannikainen, Vanhan Suomen, 168.

${ }^{43}$ Nordenstreng, Haminan, 504. 
seafaring traditions - and as protectionist legislation as did Sweden (and Finland); thus the majority of export and import cargoes were carried by foreign vessels. For example, in 1847 only 12 per cent of the ships arriving in Russian ports were flying the Russian flag. ${ }^{44}$ One must keep in mind that it was only a hundred years since Peter I had established St. Petersburg to obtain a harbour on the Baltic. Quite an important share of the vessels under the Russian flag during the early $19^{\text {th }}$ century was, in fact, either Greek or Finnish. According to one calculation during the 1880s, up to 40 per cent of ships sailing under the Russian flag were actually Finnish. Thus it was not until the turn of the $20^{\text {th }}$ century that the Russian merchant fleet overtook the Finnish fleet in tonnage. ${ }^{45}$

The major exogenous causes for the growth of timber exports were related to the overall economic growth in Europe and particularly in Britain, as Britain was the main market for Finnish timber (and tar) exports. However, the institutional changes in British markets were fairly decisive for the growth of timber exports. Namely, until the 1820s timber was mainly carried to other areas such as the Netherlands, Portugal and Spain, as the British customs duties on northern timber made it unprofitable to enter this market: in the 1820 s up to 90 per cent of the price of timber in Britain imported from Nordic countries was caused by customs duties, freight and other costs. ${ }^{46}$ The incremental abolition of customs duties on foreign timber in Britain, and consequently the ending of British preferences for colonial imports, can be clearly seen in the rise in Finnish timber shipments in Figure $3{ }^{47}$ For Finnish ship owners the repealing of the British Navigation Acts in 1849 enabled profitable freight shipments between Britain and her colonies, also for Finnish ships. ${ }^{48}$

\section{DOMESTIC AND FOREIGN VESSELS}

During the era of Swedish domination, the Swedish and Finnish export shipments were quite comprehensively carried by domestic vessels. As noted above, the situation on the Russian side

\footnotetext{
44 Joustela, Suomen Venäjän kauppa, 95; William L. Blackwell, The Beginnings of Russian Industrialization 1800-1860 (New Jersey 1968), 81-82.

${ }^{45}$ Hautala, 'From Black Sea', 17; Peter Davies, 'Nineteenth-century Ocean Trade and Transport', in Peter Mathias and John Davis, eds., International Trade and British Economic Growth: From the Eighteenth Century to the Present Day (Nature of Industrialization) (Oxford 1997), 73; Kaukiainen, A History of Finnish Shipping, 99- 100; Max Engman, 'Sjömän från Finland i Ryssland', Historisk tidskrift för Finland, 73, No. 3 (1988), 416; Åström, From Tar to Timber, 181.

${ }^{46}$ Harmaja, Suomen tullipolitiikka, 789.

${ }^{47}$ Åström, From Tar to Timber, 167, 170.

${ }^{48}$ Nikula, Malmska handelshuset, 108, 278; Palmer, Politics.
} 
${ }^{49}$ See especially Voitto Ahonen, Jälleenrakennuksen politiikka ja talous. Kaupunkien toipuminen isostavihasta noin vuoteen 1740 (Helsinki 1988); Börman, Genom Öresund; Högberg, Utrikeshandel; Jorma Pohjanpalo, Suomen kauppamerenkulku ja erityisesti linjaliikenteen osuus siinä (Helsinki 1949).

${ }^{50}$ See especially Heckscher, Merkantilismen; Magnusson, Mercantilism. - In Figure 4 the home port of the vessels passing the Danish Sound is defined through the home of the master of the ship. This so-called domicile problem has been fairly extensively studied, yet this definition is used here rather straightforwardly and needs more detailed analysis. See for example Eli F. Heckscher, 'Öresundstullräkenskaperna och deras behandling', Historisk tidskrift, 62, No. 1 (1942), 170-186; Åström, From Cloth to Iron; Åström, From Tar to Timber.

${ }^{51}$ For example Ojala, Tehokasta.

52 e.g. Sigurd Nordenstreng, Haminan kaupungin historia III (Hamina 1912), 652.

${ }^{53}$ Archives of the Fredrikshamn Town Council (Finnish National Archives)

${ }^{54}$ Nordenstreng, Haminan III, 652-659. 


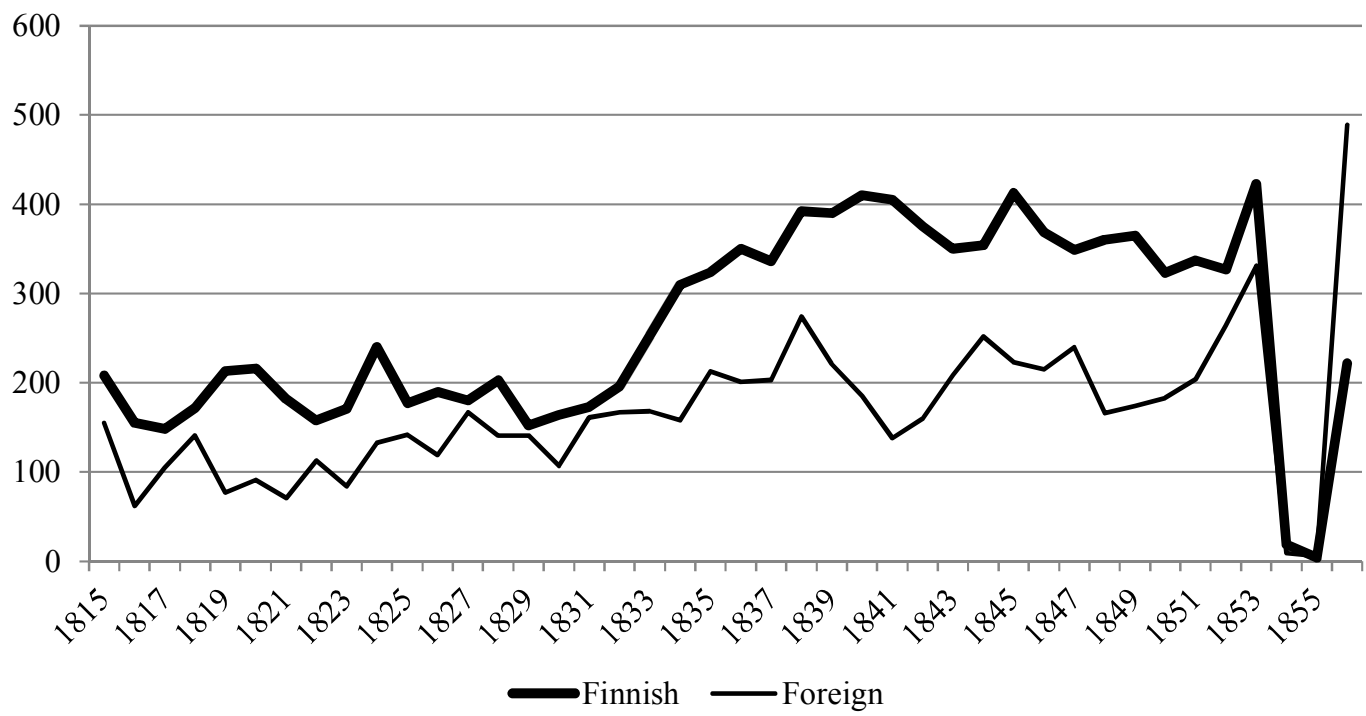

Source: STRO.

As Figure 4 shows, in some years nearly half of the ships passing through the Danish Sound either bound for Finland or leaving Finland were owned by foreigners. This share was higher with ships sailing from Finland (40.2 per cent) than for the number of ships bound for Finland (36.8 per cent). The number of ships sailing from Finland was higher $(\mathrm{N}=11,722)$ than the number bound for Finland $(\mathrm{N}=6,404)$, which can be explained by various different types of triangle trades. Namely, ships entering the Baltic typically first carried a cargo to St. Petersburg or some other large town on the Baltic, and then took on board a return cargo of timber from Vyborg or another Finnish port. ${ }^{55}$ Thus, as the number of ships leaving Finland was higher than the number that were bound to Finland, one can conclude that the Navigation Act secured imports but not exports - as indeed was its main purpose.

The increasing importance of Vyborg ${ }^{56}$ both in Finnish exports generally and in shipments on board foreign vessels particularly is seen in that some 35 per cent of ships departing from Finland through the Danish Sound came from Vyborg and the corresponding figure for ships entering the Baltic bound for Vyborg was 33 per cent of all ships bound for Finnish ports. (Table 1) The number of ships sailing from Vyborg through the Sound in the early nineteenth century was three times higher than in the second largest Finnish town Björneborg (in Finnish Pori) with a share of some ten per cent in Sound Toll records. However, the share of foreign vessels

\footnotetext{
${ }^{55}$ On these triangle trades with American ships see especially Ahonen, From Sugar Triangle.

${ }^{56}$ Vyborg and Fredrikshamn became even more important in timber exports as certain restrictions on sawmilling were lifted in 1817.
} 
departing from Vyborg was 87 per cent and of those bound for Vyborg through the Sound was 85 per cent respectively; in the case of Pori, the share of foreign ships in export trade was below ten per cent. Also in Fredrikshamn, the town close to Vyborg and also having likewise been earlier a part of Russia, the two thirds of ships passing through the Sound on leaving Finland were owned by foreigners.

Table 1. Number of ships passing through the Danish Sound from certain Finnish towns, $1815-$ 1856

\begin{tabular}{lccc}
\hline Town & $\begin{array}{c}\text { Number } \\
\text { of ships }\end{array}$ & Foreign \% & $\%$ all \\
\hline Vyborg (Viipuri) & 4,074 & 87 & 35 \\
Björneborg (Pori) & 1,196 & 9 & 10 \\
Christnestad (Kristiinankaupunki) & 976 & 18 & 8 \\
Uleåborg (Oulu) & 888 & 17 & 8 \\
Helsingfors (Helsinki) & 834 & 15 & 7 \\
G.Carleby (Kokkola) & 705 & 5 & 6 \\
Åbo (Turku) & 570 & 8 & 5 \\
Jacobstad (Pietarsaari) & 435 & 4 & 4 \\
Vasa (Vaasa) & 398 & 7 & 3 \\
Fredrikshamn (Hamina) & 377 & 66 & 3 \\
Others & 1,269 & 19 & 11 \\
Total & 11,722 & 40 & 100 \\
\hline Source: STRO. Note: names in Swedish (Finn nam
\end{tabular}

Source: STRO. Note: names in Swedish (Finnish names in parenthesis)

The Sound Toll data does not necessarily reveal exactly where the ships were bound for, especially if they were leaving the Baltic Sea: in many cases the Danish officials just noted "to North Sea" in the records. During the early nineteenth century these records became increasingly more accurate in this regard: the share of ships leaving Finnish ports and entering the "North Sea" declined from some 30 to 40 per cent in the 1820 s, and to below 10 per cent by the turn of the 1840s and 1850s. (Figure 5) At the same time the share of ships recorded to be bound for the British Isles increased from around 30 up to 50 per cent. Thus, it is highly likely that a considerable share of the shipping previously registered as bound for the North Sea was actually bound for Britain. Thus, in practice, the share of ships bound for Britain was well over 50 per cent throughout the time period.

Figure 5. The major destinations of shipping from Finland 


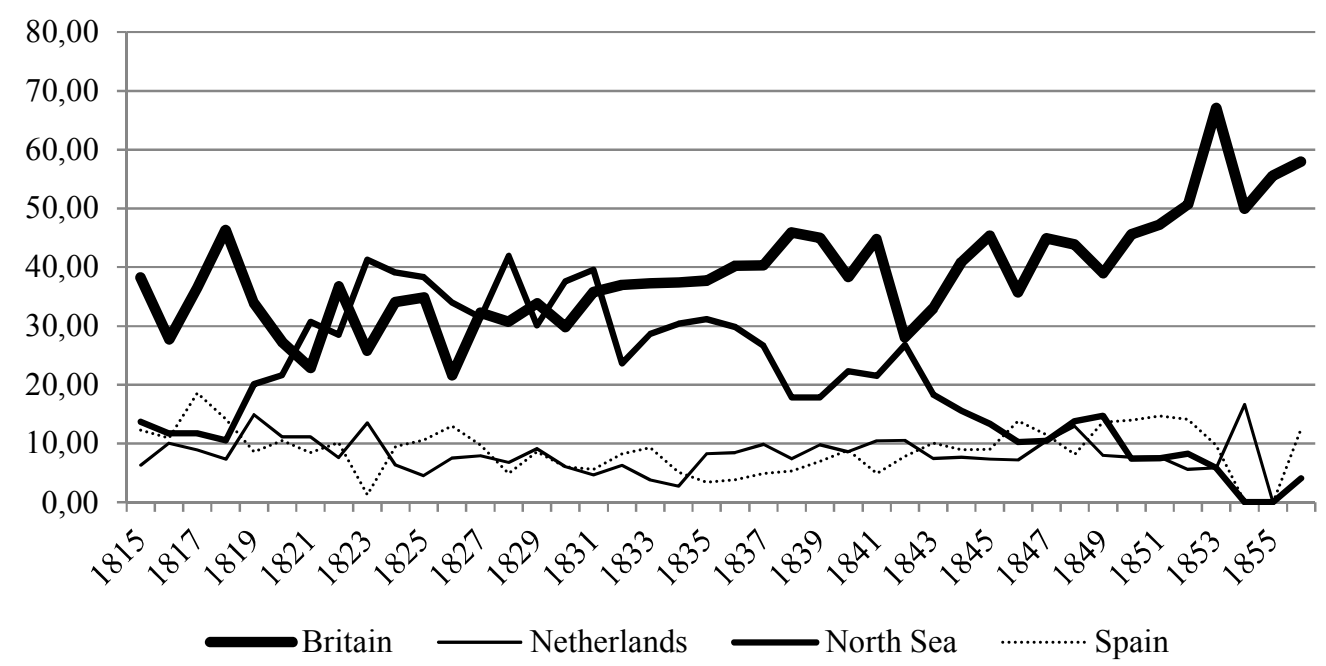

Source: STRO.

The British dominance in Finnish exports and shipping can be further witnessed in the share of British vessels of foreign ships sailing to and from Finnish ports through the Danish Sound.

Namely, throughout the early nineteenth century some 50 per cent of the foreign ships entering or leaving Finland were British, totalling over 3,500 vessels. As Table 2 shows, around 20 per cent of all vessels and 40 per cent of those British vessels were from Newcastle, followed by (South) Shields with a 14 per cent share and Hull with 11 per cent share - the rest of the British seaports accounted for fewer than ten per cent each from ships either departing or approaching Finland through the Danish Sound. An interesting piece of information yet to be further studied is the fact that from Hull around the same number of ships docked at Vyborg as departed. This therefore suggests that there were direct shipping routes between Hull and Finnish towns (particularly Vyborg), whilst in the cases of both Newcastle and (South) Shields the share of sailings from Vyborg was almost double the number of ships entering Vyborg with cargo through the Sound. This, in turn, suggests that the ships from these towns were engaged in triangle trade in the Baltic - most likely first landing a cargo at St. Petersburg, then sailing in ballast to Vyborg to take on timber to be carried back to Britain.

Table 2. Home ports of foreign ships sailing to and from Finland through the Danish Sound $1815-1856$ 


\begin{tabular}{lcc}
\hline & $\mathrm{N}$ & $\%$ \\
\hline Newcastle & 1,428 & 20 \\
(South) Shields & 503 & 7 \\
Hull & 399 & 6 \\
Sunderland & 318 & 5 \\
(Kings) Lynn & 304 & 4 \\
Lubeck & 213 & 3 \\
London & 186 & 3 \\
Copenhagen & 183 & 3 \\
Others & 3,531 & 50 \\
Total & 7,065 & 100 \\
\hline
\end{tabular}

Source: STRO.

The foreign ships were mainly used for carrying cargoes of timber. During the period from 1814 to 1857 in total 50 per cent of timber cargoes were carried by Finnish ships, while the share of domestic ships carrying cargoes of tar was 94 per cent. From the major import trades the domestic ships dominated the shipments as 83 per cent of salt imports were carried on board Finnish ships. Indeed, the primary motivation for the Swedish Navigation Act was to prevent imports with foreign hulls. This seems to have been the case even during the early nineteenth century when the bulk of the foreign ships either carried cargoes to some other Baltic ports or arrived in Finland in ballast.

Finally, besides the structural change in major exports from tar to timber, the early nineteenth century also witnessed a change in economic geography in Finland. The rise of south-eastern Finland due to timber exports was obvious. At the same time the tar-producing and exporting area in north-western Finland (Ostrobothnia) slowly lost its important role in the Finnish economy. Nevertheless, over 54 per cent of Finnish ships passing through the Danish Sound were owned by Ostrobothnians; however, the share declined from around 70 per cent in the late 1820 s to below 50 by the late 1840s. Besides south-eastern south-western Finland also grew rapidly in the period. This also manifests in passing through the Danish Sound: this area, which includes cities like Turku (Swe. Åbo), Pori (Swe. Björneborg), and Rauma together accounted for a quarter of all Finnish shiping passing through the Sound. Another area that emerged at the time was southern Finland with Helsinki (Swe. Helsingfors) as the major seaport. It was only in the early autonomous period that the Finnish capital was moved by the Russian authorities from Turku ( $\mathrm{boc})$ to Helsinki. Besides building the new administrative centre, businesses also emerged in Helsinki. This is seen in the increasing share of ships from Helsinki and the surrounding small towns passing through the Danish Sound; the proportional share of southern Finland for the whole period was around 14 per cent. Most interestingly though, the share of 
south-eastern Finland of ships sailing from Finland was about 41 per cent for the whole period, its share of Finnish owned ships was only around seven per cent. This further demonstrates the prominent role played of foreign ships in carrying exports from this area.

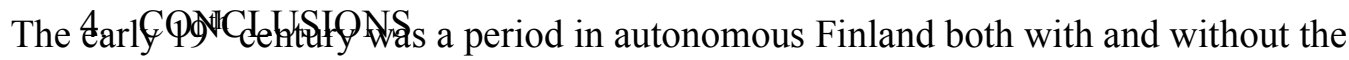
protectionist Navigation Act. This affords us a research setting to analyse the importance of this mercantile legislation. This period also witnessed growth and structural change in Finnish export trade and shipping. This study is also a first attempt to analyse the recently digitalized Danish Sound Toll Customs Accounts to re-evaluate shipping and trade from and to Finland during the early nineteenth century. This data showed that the role played by foreign ships was far more pronounced in shipments from Finland during the period than has previously been suggested. This, in turn, was related both to endogenous and exogenous institutional and market related factors. Primarily, the return of the Vyborg area to Finland after the country's annexation to Russia totally changed the structure and volume of trade and shipping: timber superseded tar as the most important export item, and the Swedish Navigation Act could not prevent foreigners from taking part in these shipments from southeastern Finland. Simultaneously, the decline of customs duties for foreign timber made it possible for Finnish and other Nordic timber exports to enter British markets. As these timber exports increased significantly there simply were not enough domestic ships to carry these goods; thus using foreign vessels was a matter of necessity. However, the import commodities (salt) seemed to be still in the domestic province - as was the major objective of the Commodity Ordinance/Navigation Act in the first place. The structural change in Finnish exports also changed the economic geography of the country as the dominant role moved from tar-producing and exporting Ostrobothnia in the north-west to timber exporting from the Vyborg area in the south-east.

The study shows that protectionist measures such as the Swedish Navigation Act vanished already before they were banned due to the growth in demand for timber exports from southeast Finland. Moreover, the article suggests that the criticism levelled at the Navigation Acts, for example by Adam Smith and Anders Chydenius, were correct: de-regulation induced growth of trade. However, with this data it is not possible to analyse the exact effect of regulation and non-regulation, as there were simultaneously numerous forces affecting 
Finnish export trade and shipping, including the overall growth of trade, and also a number of institutional changes. The institutional forces affecting these processes came from four directions. First, the old Swedish legislation was still in force in Finland. Second, the area of "Old Finland" was first under the restrictions of the Russian legislation, which might have formally abolished but not in reality. Third, the institutional changes in the major market country, Britain, profoundly influenced the increase in demand for Finnish export products. Fourth, autonomous Finland was able to introduce her own legislation and regulations though under Russian rule - but these had only minor role to play in this context. These institutional contexts should be studied more precisely in future research.

The activities and attitudes of Finnish or foreign businessmen engaged in export trades or shipping are not analysed in this paper. However, in light of the indirect evidence from the macro development, one might assume that the businessmen in south-eastern Finland were more motivated to invest in sawmills than in shipping. This was due to three reasons. First, liberal Russian policies during the eighteenth century did not restrict the use of forests for timber exports, nor did the Russian authorities try to keep shipping in domestic hands. Secondly, there was a growing market for timber exports. Thirdly, transport capacity was available at a reasonable cost - thus, it was more profitable to invest in sawmills than shipping. The situation was totally different on the west coast of Finland, being under strict Swedish protectionist legislation both in terms of the use of forest resources and domestic vessels in import trade. Furthermore, the major export item of the area, tar, did not require investments in production capacity as it was produced by peasants with rather simple methods. Thus businessmen in this area were more motivated to engage in building shipping capacity to transport cargoes of tar. Furthermore, ship owners on the west coast of Finland, in Ostrobothnia particularly, had already established themselves in the international freight carrying business, which in turn motivated them to make further investments in shipping capacity.

Finally, the rise of timber exports and the large share of foreign ships in carrying these goods witnessed the integration of the Finnish economy into the rest of Europe at the time. This integration was, however, British led, which can be seen in the overwhelming role played by Britain both as the market for Finnish commodities (more than during the previous century), but also British shipping in Baltic carrying Finnish export commodities. Moreover, the end of the Napoleonic wars enabled stable growth in exports and in shipping; although Finnish 
shipping did benefit for certain years of the French revolutionary and Napoleonic wars from the neutrality of shipping with significant profits from trade. Nevertheless, the era was rather chaotic when compared to the long and peaceful early $19^{\text {th }}$ century - that from the Finnish perspective ended in the Crimean War of 1854-55 which brought Finnish shipping and trade to a total halt.

In future more research is needed to better understand how and why the foreign ships gained such a dominant position in certain Finnish export trades. It would be of the utmost importance to study who owned these vessels and what strategies they adopted. The vessels coming from Newcastle and Hull were particularly exceptional: the first with the high frequency of carrying Finnish exports and the latter due to the fact that ships came directly to Vyborg to take home on cargoes of timber. Who organized this trade, and how are, thus, pivotal questions. 